\title{
The Charnegroes: Black Africans and the Ontological Conflict in Catalonia
}

\author{
Saiba Bayo
}

Citation: Bayo, Saiba. 2021. The Charnegroes: Black Africans and the Ontological Conflict in Catalonia. Social Sciences 10: 257. https:// doi.org/10.3390/socsci10070257

Academic Editors: Zenia Hellgren and Bálint Ábel Bereményi

Received: 12 May 2021

Accepted: 1 July 2021

Published: 7 July 2021

Publisher's Note: MDPI stays neutral with regard to jurisdictional claims in published maps and institutional affiliations.

Copyright: (C) 2021 by the author. Licensee MDPI, Basel, Switzerland. This article is an open access article distributed under the terms and conditions of the Creative Commons Attribution (CC BY) license (https:// creativecommons.org/licenses/by/ $4.0 /)$.
Department of Political and Social Sciences, Pompeu Fabra University, 08005 Barcelona, Spain; saiba.bayo@upf.edu

\begin{abstract}
This paper frames an in depth reflection on the current social and political changes and the emerging phenomenon of body politics of migrant and racialized groups in Europe. The ongoing discussion aims to address the meaning of "being" Catalan for Black Africans in Catalonia. It is grounded on a criterion of ontological commitment and the epistemological aspect of ethnography. I dig into the debate about what makes a racial identity salient in the context of national identity rhetoric. I look thoroughly at the outcomes of the encounter between Black African migrants and the constant resignification of Catalan national identity. I aim to disentangle the racial premises and tackle what Black Africans share once the racial questions are removed. My approach stands within the growing field of postcolonial criticism to understand historical continuities and ontological conflicts. I focus on culture, race, and identity to analyze the cultural dynamics of Senegalese migrants and Equatoguinean communities within the national identity building process in Catalonia. I coined a new concept, Charnegroes, to propose a practical explanation of the emergence of body politics and the changing reality of the relationship between the "us" and the "other" under the recurrent transitions between old and new, colonial and postcolonial, the past and the future.
\end{abstract}

Keywords: Charnegroes; Black Africans; Catalonia; national identity; racism; Africanness

\section{Introduction}

From the aftermath of Spain's integration into the European Union in 1986, an important number of Black Africans have settled in Catalonia, pushing the regional government to implement policies to integrate these newcomers into the Catalan society. Meanwhile, Catalonia was experiencing a process of nation building (Solé 1982; Candel 1985; Shafir 1995). Since the 1980s, the building of national identity in Catalonia has produced a passionate debate on cultural identity and citizenship (Conversi 1997; Ainaud 1980; Barreda 1985). Still today, the debate on national identity in Catalonia constitutes a controversy. Jordi Pujol-the former president of Catalonia and one of the theoreticians of "catalanity" remains the Catalan nationalist leader who deploys the most powerful political discourse to "re-adjust" the notion of citizenship to the idea of national identity in Catalonia. He then declared: "Is Catalan anyone who works and lives in Catalonia and wants to be it" (Pujol 1976).

The narrative on national identity in Catalonia unravels an ontological commitment beyond the facticity of cultural encounters. It places before us an emotional debate that encompasses awareness of being Catalan within history and the controversy surrounding the need to preserve the language, political system, and institutions Catalonia inherited from the medieval era (Cingolani 2015; Sobresques 2015). Such a debate is mainly rooted in a "utilitarian cultural orientation" (Fok et al. 2016), which implies that all those who had settled in Catalonia and had improved their living conditions and accomplished their economic aspirations would adhere to a kind of "civic nationalism" (Roshwald 2016).

However, one should wonder if the change from the status of migrant to citizen will turn them into a Catalan. The idea of being/becoming Catalan constitutes a challenge for minorities and presents a dilemma about "what exists out there" in terms of identity. It 
understands identity as an attribute or a political reification of subjectivities that relies on theoretical constructions and psychological boundaries. In this sense, even if one endorses a multicultural interpretation (Kymlicka 2010; Taylor 1992) of the Catalan national identity, he or she might expect social minorities like Black African collectives to reproduce their cultural dynamics as a subcategory of the Catalan national identity.

This paper delves into the growing field of postcolonialism ${ }^{1}$ to engage in a critical dialogue to elucidate the cultural dynamics of Black Africans in Catalonia to show how they contribute to creating new spaces for diversity in a multiracial society. It examines the relationship between the management of identity politics and the forms and conditions of representation in the context of building a national identity. Moreover, despite the extensive literature on integration policies and attitudes towards immigrants in Europe (Morales et al. 2015; Zapata-Barero 2000; Zapata-Barero et al. 2003, 2008; Hainmueller and Hopkins 2014; Penninx et al. 2014), an analysis of racialized groups that considers the phenomenon of cultural negotiation in the context of ontological conflict is still neglected.

It is then tempting to ask how the cultural background of Black African collectives in Catalonia fit with the idea of "being Catalan"? Answering this question will allow us to tackle Black Africans' cultural dynamics, either as a form of mimetism or a cosmopolitan prescription of being as part of a universal human nation. Can Black Africans in Catalonia and their descendants become Catalan? If national identity relies on historic prescripts or the cultural determinism of belonging to a group, then it would be stimulating to ask whether becoming Catalan can be the claim or the aim of Black Africans and their descendants.

I do not seek to privilege Black African migrants' rights to preserve their cultural identities over Catalonia's national identity. Instead, I intend to deal with a critical and contextual analysis of cultural negotiation in a multiracial and multiethnic society. My approach consists of assessing the social conditionings and normalizations that incorrectly assume a stable nature of identity and power relations. I rely on a criterion of ontological conflicts and the epistemological aspect of ethnography (Blasser 2013; Bricker 2016; Abid 2017), followed by a critical analysis of institutional forms of negation and exclusion. Black Africans' cultural dynamics allow us to understand their capacity to build a sphere of representation.

For a cultural dynamic is nongenetic information that is transmissible from one person/group to another, which can potentially affect the behavior (Kashima 2014, p. 3); and I compare two social groups: the Senegalese and the Equatoguineans collectives in Catalonia. For instance, I consider the sociocultural associations founded by Black Africans and their role in the dynamics of representation in discourse and the promotion of their cultural dynamics. I assess the colonial legacy and the postcolonial realities of these two groups. I consider three headings: (1) The management of integration policies and the rhetoric of national identity in Catalonia. (2) The cultural dynamics of Black Africans in the broad context of postcoloniality. (3) The emergence of the body politics of the charnegroes ${ }^{2}$, based on the exhibition of Blackness by Black African descendants.

I examine essays, novels, stories, academic literature, and newspapers, combined with interviews, observations, and debates with members of both the Equatoguineans and Senegalese collectives. I begin by discussing the rhetoric of national identity and its impact on some aspects of integration policies in Catalonia. Later, I address the colonial legacy, ontological commitment and cultural practices of the Senegalese and the Equatoguineans. Finally, I coined the new concept of Charnegreos to assess the cultural encounter and define the emergent "body politics" (Brown and Gershon 2017) shaped by Black African descendants in Catalonia. The results offer new paths to understand the complexity of cultural encounters and how migration and mobility play into this identity construct. It offers the possibility to undertake research on the cultural dynamics of Black African collectives in Catalonia and provides some conceptual tools to challenge the possibility/impossibility of becoming Catalan for a category of citizens. 


\section{Theoretical Discussion}

The triumph of ideologies hostile to cultural diversity and the changing phenomenon of global migration requires new conceptual spheres that can tackle the complexity of cultural dynamics and national identity in a multicultural and multiethnic society. The early ideas that one usually has in mind when considering national identity often connect us with the visible aspects of national symbols such as monuments, the buildings, the national flag, anthem and motto. Doubtlessly, these elements represent strong emotional ties and shape a feeling of belonging to a group and an environment, underpinning the right to claim a common history. Nevertheless, there are also abstract or nonrational factors such as languages, symbols, beliefs, legends, or stories that are relevant in shaping the national identity.

Edouard Glisant is undoubtedly one of the postcolonial thinkers whose contribution to national identity remains crucial. Almost all of Glissant's work explores the conscious construction of a collective identity. For instance, he considers national identity as the prelude to resistance and national liberation (Glissant 1981). However, such a perspective of national identity has undergone considerable changes throughout Glissant's career. Identity is also the result of profound changes and transformations in contact with the other (Glissant 1990). In this sense, the concept of identity fluidity will end up determining Glissant's positioning. Indeed, Glissant believes that it is through contact with others that one discerns different ways of being and frames one's identity based on intercultural exchanges (Glissant 2006).

Frantz Fanon's influences in the formulation of Glissant's earlier theoretical work is remarkable. National consciousness and national culture are two fields of criticism that attract Fanon's attention. Regarding culture, Fanon holds that "Extracted from the past to be displayed in all its splendour, is not necessarily that of his own country" (Fanon 1963, p. 211). Substantially, national consciousness concerning culture is also the fruit of institutional performance. As Fanon writes: "National consciousness, instead of being the all-embracing crystallization of the innermost hopes of the whole people, instead of being the immediate and most obvious result of the mobilization of the people, will be in any case only an empty shell, a crude and fragile travesty of what it might have been" (Ibid, p. 148).

Arguably, national identity aims to define peoples according to what they should (or could) be, instead of who they are and where they belong; its construction implies (or requires) the suppression of the cultural identities of minority groups (Rex 1996; Scott 1990). National identity then places us before an ontological conflict, for it tries to simplify the competition between different realities and the multiplicity of histories, cultures and subjectivities. Ontological conflicts emerge as forms of contestation in the context of political and ideological reification, which claim to reduce the existence of communities to a simple convergence of identities.

Ontological conflicts are, therefore, the result of the resistance to the modern assumptions of cultural hegemonies and the colonial mimesis. Mario Blasser (2013) identifies two headings in approaching ontological conflicts in social sciences: First, "to consider ontological conflicts as a possibility, one must question some of the most profoundly established assumptions in the social sciences, for instance, the assumptions that we are all modern and that the differences that exist are between cultural perspectives on one single reality" (Blasser 2013, p. 1). The second heading has a methodological feature, for it outlines that "ontological conflicts pose the challenge of how to account for them without reiterating (and reenacting) the ontological assumption of a reality "out there" being described" (ibid).

We should bear in mind that beyond the controversy on cultural encounters, the story of the postcolonial world is the history of a hegemonic world order shaped by the clichés of an "overhang universalism" (Diagne and Amselle 2018). From these remarks, it becomes necessary and even demanded to consider, at least through our research methods applied in social sciences, that "there are also histories of the diverse traditions and practices that cannot be reduced to ways of generating surplus or of conquering and ruling others" (Asad 1973, p. 49). 
Suppose one acknowledges the right—of the State or a political entity—to build a national identity by imposing a cultural standard for all. In that case, it should be crucial to be aware of the desire of minorities to keep existing according to their ways of life. For instance, during colonialization, the colonial empire imposes different cultural standards on building a sense of belonging to a (French, British, Spanish, etc.) nation. In this sense, the central inquiry is that colonialism produces the cultural encounter between the West and the nonwestern world that had induced the profound ontological conflict between "intimate enemies" (Nandy 1983).

Nowadays, formerly colonized peoples and their former colonizers share a common space under postcolonial uncertainty. This coexistence becomes a complex issue in global migration, where the formerly indigenous have evolved to the status of second class citizens (Cash and Kinnvall 2017). The claim for particularities imposes overcoming the colonial rationality. However, forty years after Claude Levi-Strauss proposed methods to innovate social and cultural diversity, Samuel Huntington will point out the danger of the "Clash of Civilizations" (Huntington 1993). In sum, the anxiety of the postcolonial transition exacerbates the tensions between the identities of dominant groups and subalterns (Spivak 2010).

In that context, fostering a national identity remains crucial in Europe. For instance, in Democracy without Nations? Pierre Manent's (2007) approach of rethinking the social world in Europe oscillates between colonial anthropology and the dogma of frozen identities. Manent failed to propose a practical explanation of the social European. Instead, he paints a "self-schema" of Europe, grounded in the foundations of a nation state. His idea of national identity is simplistic, essentialist and monolingual. Manent writes: 'Our languages do not express a sublime "cultural" essence that is fundamentally apolitical or metapolitical. Rather, they express the history of our respective political regimes' (Ibid, p. 30). Thus, for Manent, European cultural values encompass the totality of universal principles, rely on a "moral compass" and cannot coexist with other cultures; thus, it cannot contemplate cultural diversity as political expression.

Accordingly, the concern for national identity in European democracies highlights a passionate debate on identity politics. The general trends of identity politics, according to Jürgen Habermas (1998, p. 48), consist of the "democratic management" of the public sphere and the establishment of a normative and cultural "framework" that would apply to all. These republican principles continue to influence policy making on identity politics in European democracies. Beyond, it shapes the foundations of political rhetoric and reveals a fear that the cultural practices of some migrants could undermine national identity.

Meanwhile, multiculturalism emerged as a theory of cultural diversity to tackle conflicts of coexistence in a multiracial society. One of its well known theorists, Charles Taylor criticizes the modern notion of identity (which includes national identity) in western democracies. Taylor asserts that radical identity management is embedded in a liberal view and follows two main models of politics: a "politics of difference-blind", which focuses on the idea of the recognition of the unique identity of each individual or group, and a "politics of equal dignity" that relies on the idea of equal dignity for all the citizens (Taylor 1992, p. 42). However, both models have followed the notion of public good, have failed to manage the problem of recognition, and have promoted a discriminatory view of identity.

Other scholars have severely criticized multiculturalism, which they consider obsolete and unable to provide a practical explanation of the complexity of the current social and political reality (Chapman 2010; Ercan 2012; Levey 2009). Postmulticulturalism (Kymlicka 2010; Vertovec 2010) was then expected to better understand present social and political changes, such as the changing nature of global migration, new social formations, and the persistently weak socioeconomic standing of immigrant and ethnic minorities (Vertovec 2010). Postmulticulturalism might help to better accommodate social minorities and foster, at the same time, national identities.

However, postmulticulturalism entails significant paradoxes, for it reinforces rather than counteracts the problematic features of multiculturalism (Gozdecka et al. 2014, p. 51). 
In recent years, the narrative of the integration of migrants in Europe appeals to a hierarchical view of the society, promotes the imposition of western values, and does not fully recognizing the possibility that the cultural dynamics of immigrants can coexist with the culture of the host society. The white paper of the Council of Europe highlights that "[Strategies for integration must necessarily cover all areas of society, and include social, political and cultural aspects ... ]" (Council of Europe 2008, p. 11). However, the vagueness of its contents means that immigrants from nonwestern countries would have to abide by the laws but also the cultural heritage of Europe.

\section{Integration Policies and National Identity in Catalonia: A Taxonomy}

After Pujol published his essay on Immigració: problema i esperança de Catalunya in 1976, he defended his work by saying that he had intended to avoid jeopardizing Catalans. ${ }^{3}$ However, "behind this supposedly inclusive speech and politically correct, they exist and have existed in Catalonia situations of marginalization and social exclusion towards immigrants" (Clua 2014, p. 37). Pujol's assumptions rely on a strong political agenda and reveal the concern for setting a benchmark for the nationalist project. He adopts orthodox "cultural politics" (Vertovec 2011) to foster a collective national identity; maybe to claim for a sovereign state or the right to decide which relationship with Spain Catalonia deserves (Vázquez 2013b; Guibernau 2014).

The idea of "being Catalan" is embedded in historical essentialism muddled with geographical conditions, for it claims that "the set of mountains, plains, rivers, wetlands, forests, beaches, caves that constitute the territory of Catalonia, has contributed powerfully to make the Catalan as they are. It has helped to cut out the character of people of Catalonia" (Parés and Borràs 1999, p. 4). Thus, "being Catalan" entails the assumption of propositions that conceive the nation of Catalonia as fixed and homogeneous entities that express the particular spirit of a particular people-the people of Catalonia-who remain circumscribed to a culture, a history and a territory.

During the 2010 regional elections, Artur Mas appealed to a strong emotional political message through the slogan "the will of the people". Mas had a specific idea about the significance of the "people of Catalonia" which proved to be a very closed concept determined according to a racial construction. For him, "Catalan cultural DNA is shaped during the belonging to the Franco-Germanic world. Thus, something must remain in our DNA, because Catalans have umbilical ties with their past that makes us more Germanic and less Roman". ${ }^{4}$ Otherness characterizes the construction of national identity in Catalonia. For instance, the term "charnego" was coined to identify the children of mixed marriages between Spanish migrants and native Catalan (Clua 2011; Aramburu 2016). However, the term will later be extended to all native Catalan of Spanish descendants. Montserrat Clua i Faine places the origin of the word around the 1490s however, she explains that it was from the 1970s that it acquired a pejorative meaning in Catalonia (Clua 2011, p. 67).

This racial conception of Catalan identity has deeply stained the perceptions of integration policies. Two dimensions constitute the backbone of Catalan integration policies: (1) participation in public culture and (2) promoting the Catalan language to build public culture. Catalan authorities conceive integration programs to promote participation in public life and coexistence in a religious plurality by maintaining a good level of coexistence and offering many people opportunities for better lives (Generalitat 2014). However, politics has often been limited to more or less rigid protocols, which have not been far beyond the providing of language assistance to newcomers and public officers (Carbonell 2006). Integration politics often relies on discriminatory programs influenced by political discourses (Rubio-Carbonero and Zapata-Barrero 2017).

The action program of Catalan identity politics pursues the purpose of the educational success of the children of immigrants, social inclusion of vulnerable groups of immigrants, and access to public services by immigrants (Generalitat 2017, pp. 22-23). Such a proposal may achieve the recognition and inclusion of all, regardless of their origin and cultural background. Political participation in Catalonia is salient in the political slogans underpinning 
the moral standards of the institutions. However, the achievement of equality, inclusion, diversity, and respect remains a basic discourse, and its implementation is superfluous. For instance, equal opportunities for all is still at the stage of conceptualization and the right to vote of immigrants is subordinate to external factors despite the endowment of institutions on this issue.

The Catalan language is considered the "common public language for all citizens" (Generalitat 2008). For instance, in 2004, Catalonia's authorities launched the schooling plan for migrant children who were born outside of Catalonia and arrived at schooling age. This was supposed to be a pragmatic action program to achieve the full integration (Carbonell 2006, p. 9). However, it embraces the ideological assumption that the teaching of the Catalan language determines the interaction of students from other countries (Generalitat 2005). Doubtlessly, the content was not intended or designed to be adapted to the needs of the immigrant's children. On the contrary, it requires that migrant children adapt to the cultural reality of Catalonia. That poses the serious problem of learning for most immigrant children, especially those of Black African communities.

Migrant integration has been a controversial social issue to which institutions and concerned agents have tried to provide some solutions. For instance, in 2008, left wing political parties and nonprofit organizations signed an intersectional pact called Pacte Nacional per a la Inmigració, "Immigration National Pact" (Generalitat 2008). The content bears on an assumption of multiculturalism even though, according to Artur Mas, it was a simple declaration of intentions. Meanwhile, Mas proposed to subordinate the citizenship of migrants to an effective integration to Catalan culture. The idea is that immigrants must identify themselves with Catalan cultural background and identity. ${ }^{5}$ Josep Antoni Duran i Lleida ${ }^{6}$ would go further, declaring that "not everyone fits here, and those who have to stay have to be perfectly integrated" ${ }^{7}$.

Arguably, some categories of migrants from west African countries who arrived in Catalonia en masse between 2000 and 2008 are seen by Duran i Lleida and Artur Mas as a threat to Catalans' culture and ways of life. The crucial point of this controversy is that the integration process begins with the migrant's contact with the host society, but we can hardly attest to when it ends. Cultural and administrative barriers raised during the process turn migrants into residual citizens and mere consumers of public services. For instance, the implementation of most proposals of integration is performed by the political parties. Likewise, CDC founded the Fundació Nous Catalan (New Catalans Foundation) to promote newcomers' integration in Catalan society. That project was an extension of the Casa Gran del Catalanisme (the great house of Catalanism), conceived by Artur Mas himself in 2007, to "refound the idea of being Catalan" 8 .

A section assigned to the Black Africans was created within Fundació Nous Catalan and was named Espai Afrocatalan (the place for Afrocatalan). "The place for Afrocatalan" was intended to promote the participation of Black Africans in Catalonia. However, the purpose of the organization was focused on promoting Catalan culture, language, and militancy for Catalonia independence. Inclusion into socalled public culture only exists in political discourses (Sepa Bonaba 2017, p. 337). The manager of the "place for Afrocatalan" had to file a lawsuit against Fundació Nous Catalans for nonpayment of his salary for two years. $^{9}$

Moreover, despite the ambitious agenda on integration and cultural diversity, the debate on racism in Catalonia is downplayed in theoretical studies on diversity management. On the contrary, due to the implication of national identity for the integration of migrants, Catalan institutions normalize the exclusion/inclusion of minorities such as Black Africans. Beyond the tolerance of racist arguments that link national identity and the management of identity politics, racism remains taboo for Catalan institutions. This institutional racism is based on a perverted alteration of cultural and sociological difference, which appears as a question of a relationship with the "other", but which are instrumentalized and broadcasted by the public institutions. 
Practices such as racial/ethnic profiling by the police, the harshness of renting a house, and hate crimes are common in Catalonia (Añón et al. 2013; Garcia Matin and Sánchez 2020). Despite Catalan institutions trying to project an image of a diverse and inclusive society, the celebration of public events, sponsored by institutions, promote phenomena like blackface. These remarks point out Black peoples' invisibility in public spaces. Beyond the actions of nongovernmental organizations like SOS Racism ${ }^{10}$, there are no concrete politics against racism. The defense of diversity Catalan institutions pursue consists of absorbing Black African cultural dynamics into a public culture, which does not differ from fostering Catalan cultural hegemony. However, we have to remember that cultural diversity does not mean the domestication of the culture of the other.

\section{Black African Cultural Dynamics}

The Black African community is racially homogeneous but very diverse ethnically and culturally. However, colonialism has obscured such "social divergence". Western and Arab domination created conditions for the emergence of new subjectivities and identities in African societies. Some identities of Black Africans are products of their interaction with other civilizations (Glissant 1997, 2006). Arguably, Black African cultural dynamics in Catalonia would be difficult to understand without examining its colonial legacy. In fact, the colonial legacy of Equatoguineans continues to influence their relationship with the rest of the Black Africans in Catalonia.

However, the main differences between the Equatoguinean and Senegalese's cultural dynamics in Catalonia are religious, linguistic, and intergroup relational (Sow 2003). In addition to this, the arrival of boat peoples from Senegal to the Spanish coasts and the popularity of street vendors, known as "top manta"11 have determined the main image we often have of the Senegalese in Spain/Catalonia. These two phenomena have overshadowed the reality and complexity of the Senegalese community in Catalonia. These differences are crucial when analyzing the groups' concerns, how their collectives are organized, and their relation with the phenomenon of national identity and integration politics in Catalonia.

\subsection{Equatoguineans between Colonial Legacy and Cultural Dynamics}

Donato Ndongo highlights the burden of the colonial legacy by considering the national Culture of Equatoguineans as "undeniably Hispano-Bantu" (de Castro Rodríguez 2019 , p. 246). This statement underpins an ontological conflict. It shows that there is no single definition of Equatoguineans as one people and that the colonial alienation had profoundly provoked the "culturally anaesthesia" of Equatoguinean intellectuals (Evita 1996). The self-identification with the Spanish culture that claims Donato relies on his assumption of the colonial legacy. However, despite this cultural alienation, Equatoguineans collectives have been struggling to preserve part of their collective memory, like most Black Africans.

For instance, Juan Balboa's (1985) autobiographical novel narrates the ambivalence and ontological conflict among Equatoguineans. Despite the sophisticated Christian education he received in Spain, the protagonist decides to return to his homeland, on the island of Bioko, to become involved in recovering the traditional spirituality of the Bubi people. In María Nsue-Angué's (2008) novel, we can appreciate the sorrows of N'nanga, Ekomo's wife, for having to bury the corpse of Ekomo in Spain and against the traditional beliefs of her people. In this novel, Maria rescues the figure of the elder, the Father of Nnanga, who guides her to recover her traditional identity. These traits are characteristics of traditional African Societies.

The point is to know which dimension of Equatoguineans' subjectivity is subordinated to the Spanish/Catalan colonial legacy. It is well known that colonial governmentality consisted of exacerbating ethnic confrontation among the colonized society. "The colonial government began to practice a policy of separation of different ethnic groups, favouring, above all, Bubies and Ndowes, and presenting them in the eyes of the Fang as the smartest, hard-workers, intelligents and, therefore wealthier. On the contrary, the Fang were lazy, uneducated, and poor. Still, they represented a permanent danger to the Bubis" 
(Ndongo 1977, p. 74). The implications of such considerations on the relationship between the groups is crucially dire.

Although Equatorial Guinea became independent from Spain in 1968, the colonial rationality is perpetuated by postcolonial political elites (Mbana 2004). The different ethnic groups find themselves in a new political reality and social context where the notion of national identity is displaced by the "Witchcraft of the Fangs" (Mbana 2004, p. 45). Mbana points out that postcolonial nationalism toils with the dynamics of subjugation led by the dominant group of the Fang people. The distortion and perversion of the history of Equatoguineans impacts the relationship between the different groups, both in Equatorial Guinea and the Diaspora, mainly present in Spain.

Catalonia became the homeland of many Equatoguineans fleeing the atrocities of the dictatorship of Francisco Macias (1968-1979) followed by the current dictator, Obiang Nguema. One can expect that the historical connections that tie Equatoguineans to their colonial legacy continue to influence the intergroup relations of the different groups. However, it is important to pay attention to tensions between Spanish mainstream cultural heritage and Equatoguineans' ways of life. Equatoguineans in Catalonia have created new spaces and set up new forums to talk about themselves and tell their histories and experiences. For years, they organized events and established forums to transmit their histories, values, and culture, and to teach their children their languages. They undertake a collective project to remember and practice their traditions and spiritualties, tell their stories and rewrite their history outside Spanish/Catalan institutions.

The collective dynamics of Equatoguineans is not often linked to the national identity of their country of origin, nor to the Black African cultural demonstration. The weight of the Spanish cultural heritage often inhibits their possibilities of undertaking a challenge to Spanish/Catalan institutions. Their closeness to the Spanish/Catalan cultural background and the disconnection with Black Africans have possible explanations. Sharing part of the Spanish/Catalan cultural heritage entails an ontological commitment. Equatoguineans use the Spanish language and their children born in Catalonia speak both Catalan and Spanish. Even the children of those married to their fellow (racially and ethnically speaking) communicate between themselves in Spanish or Catalan. Most of them do not even speak the African language of their parents (Sepa Bonaba 1993, p. 33). However, the reaction of Equatoguineans before the Catalan integration policy is marked by a cultural duality.

\subsection{The Preserving the Collective Memories among the Equatoguineans}

"I have been living in Catalonia since I was seventeen, and I somehow feel Catalan. However, I cannot stop being Bubi for it". ${ }^{12}$ Most Equatoguineans have achieved primary studies before their arrival in Spain, and many others have continued to higher education (Fall 2017). This means that integration into the host society is less problematic than that which we can understand among other Black Africans. The cultural background and their concern for political life are quite different from most of the Black African collective. Although their collective's fragmentation weakens the intergroup relationship within their community and among Black Africans. However, the vindication of their peculiarities has maintained their cultural dynamism.

The Equatoguinean collective in Catalonia (but also in other parts of Spain) founded four sociocultural associations, according to ethnic affiliation, to encourage sociability and foster their traditional identities cultural identities. For example, the association Rieba-pua groups the Bubi, the Viyil represents the Anobonese (ambö), the Fangs created the Biafang, and the Ndowe founded Rhombe. These ethnic based associations had promoted successful cultural events in Catalonia. Nevertheless, there is still a feeling of nonrecognition and a lack of actions that promote their inclusion. "During thirty years our associations are involved in organizing events to promote our culture. However, there is still no clear policy to promote our participation as part of the society."13

Bubi collectives have been involved in organizing celebrations like the day of " $\mathrm{E}$ 'lo e Ritta" that allow them to bring their children together in a single space to teach some 
aspects of Bubi Culture and history. They also celebrate other events such as the Bisila and the day of "E'lo oté e Ria". These celebrations offer the opportunity to learn the traditional Bubi spirituality and help to strengthen brotherhood. However, the particularity of these events is the considerable trait of syncretism due to the influence of Christianism. All these celebrations constitute a resistance mechanism against Catalan/Spanish cultural assimilation.

Due to the reduced number of the collective membership, the Ambö founded the association Viyil to foster intergroup relationships. Viyil means parliament in Annobonese. The association enables Ambö to recreate a symbolic representation of the traditional political sphere. The purpose consisted of promoting the Annobonese Culture among native and other collectives while they inform about the reality of the island of Annobon and the dictatorship of Equatorial Guinea. The Ambö selfpublished the "VIYIL" cultural outreach magazine. According to the former president of the association, "Our main action is focused on disseminating the pieces of information and the news they receive from the Island of Anobon to denounce the repression of its people by the Obiang Ngeuma's dictatorship." ${ }^{14}$.

Although some of these associations still exist officially, most of them are no longer operating. We must bear in mind that the particularity of the Equatoguinean community (e.g., its fragmentation and its ethnic orientation) in Catalonia complicates the articulation of collective dynamics. However, the lack of support from public institutions makes it difficult to develop cultural activities through their associations. The promotion of cultural events undertaken by these collectives would foster diversity. Since some characteristics of Equatoguineans' cultural dynamics reflect some aspect of cultural resistance, an analysis of the relationship between the Senegalese's cultural practices can reveal interesting information to continue to deal with ontological conflict.

\subsection{Senegalese Collective Consciousness and the Question of Representation}

The first Senegalese associations created in Catalonia were informal organizations that brought together immigrants from a specific area (town, village or region) in Senegal. They were mainly focused on gathering funds to help members who were sick, expatriate corpses, assist their fellows in administrative regularization, job search and housing (GiróMiranda and Romeu 2013). However, as the population of Senegalese migrants in Catalonia increased, the registration of associations went up as well. Around 2015, the Senegalese community had registered almost 200 associations, but only about 80 were operating. The majority of these associations were founded to undertake social and communitarian projects (school, hospitals, services) in their area of origin. ${ }^{15}$

The community undertook a collective dynamic to promote intergroup relationships between the different organizations and strengthen ties with their country of origin. Hence, in 2003, they founded the Federation of Senegalese Associations of Catalonia (CASC). Therefore, the priority of the CASC is to carry out a diagnosis to find the tools that enable them to combine different sensibilities around the specific issues that affect the Senegalese community.

The strategy of CASC consists of promoting dialogue between Catalan institutions and the community, while fostering their members' religious and traditional practices. This allows them to filter some information and avoid a possible crash. Although most the associations are not affiliated-due to the informal nature and the programmatic orientationsCASC constitutes one of the best solutions for cultural intermediation. Founded by an immigrant community, its institutional dimension makes it the ideal interlocutor between Senegalese collectives and Catalan institutions.

Senegalese migrants deploy dynamics to correct some discriminatory aspects of integration policies that harm the interest of their community members. Due to cultural and linguistic barriers, many Senegalese have to struggle to fulfil the schooling of their kids in an environment that requires them to become a citizen under the new cultural burden of 
Catalanity. The context poses a challenge, for compulsory schooling does not fit with the traditions and the reality of the majority of Senegalese migrants.

Most Senegalese migrants are Muslim, which means that most were sent to Koranic school during their childhood. Consequently, even if their children have to attend public school in Catalonia, it is common to see an informal organization of Senegalese that allows them to send their kids to afternoon classes to learn Koran and Islam's practices. Moreover, due to the French colonial heritage, official public education in Senegal is highly elitist (Sabatier 1978). It is common in Senegal to abandon basic schooling to learn a trade or profession in an informal school.

We should add that some aspects of Catalan integration policies provoke negative attitudes towards Catalan institutions among Senegalese communities. There is neither an explicit protocol nor a clear idea about including foreign culture in the teaching of migrant children. Catalan integration policies propose generic texts where specific mentions are made to inclusion and equal opportunity for all, but when push comes to shove, each school manages matters as they please. This induces some parents' lack of participation in public spaces, such as school's parents' clubs, where their presence is crucial for their children's schooling.

Leaders of the Senegalese collectives are aware of this problem, and they know that "Catalan institutions will not facilitate access to public spaces. They probably don't know how to do it, because they ignore our reality. That is why we will have to conquer those spaces by our own strategies". ${ }^{16}$ CASC has implemented different programs to fill the gap created by the integration policies. The strategy of CASC can be considered a cultural resistance, for their cultural dynamics are focused on creating a space for participation in their community while maintaining institutional relations with Catalan institutions. Despite this close relationship, being or becoming Catalan is not a concern.

\subsection{The Dynamics of Cultural Resistance}

The Senegalese filmmaker, Ousmane Sembène, depicts the clash of civilizations (African, European and Arabic) in his film Ceddo (Sembène 1977). Ceddo is about the beginning of French colonization in the 19th century while Islam, through the Almoravids ${ }^{17}$, was consolidating its influence in Senegal. During colonization, two forms of cultural movements-led by Muslim leaders and native popular communities-emerged simultaneously to wage resistance against the colonizers. ${ }^{18}$ The Islamic brotherhood then focused their religious practices and preached to contain French cultural alienation (Grandhomme 2009; de Jong 2010; Diouf 2000; Bruschi 2005). Encouraging nonviolence in the resistance against Western cultural domination, these religious organizations remain influential in the social life of the Senegalese.

In Catalonia, there is a strong representation of these religious brotherhoods. As in their country of origin, Senegalese migrants replicate the cultural dynamics and forms of organization of the Islamic brotherhoods. Likewise, murid celebrate the Magal to remember Ahmadou Bamba's ostracism by the French colonial administration from 1895 to 1907. Members of the Malick Sy brotherhood and Baay Ibrahim Nas identify themselves with the tijaniyah. The Malick Sy brotherhood followers proclaim themselves tijan, while the followers of Ibrahim Nas coin the appellation talibe baay (disciples of Baay). They celebrate events following the tijaniyah calendar but also with the so called Gamu (spiritual retirement). The brotherhood of the Layen is very singular among Senegalese religious organizations. In Senegal, they are mostly settled in the suburb of Dakar. In Catalonia, members of the Layen brotherhood celebrate the anniversary of the death of Limamou Laye every year.

The Dahira (Islamic school and place of spiritual retirement) is the name given to the Senegalese Islamic brotherhood organizations. The membership of a Dahira is open to everyone, and the Dahiras are known for their hospitality towards newcomers. Most of them play the role of "social house" for immigrants in need of help. Due to their religious patterns, the Dahiras are the best organized and operating organizations among 
the Senegalese immigrant collective. They are autonomous, nonprofit and selffinanced organizations that often carry out their activities outside the institutional framework.

We have eight Dahira of the murid brotherhood in Catalonia, seven Dahira of tijaniya (two of them are managed by the Talibe baay), and four Dahira of layen. Membership neither requires belonging to a specific ethnic group nor being from a particular part of Senegal or the world. ${ }^{19}$ Dahiras do not defend ties to a region, a city or town of Senegal. They do not even claim Senegalese nationality. Each of these organizations has its calendar of events related to a specific moment of their history. The organization of these events serves to ground their collective consciousness and strengthen their intergroup relationships.

Apart from the Muslim brotherhood, Christianity's followers also have their communities and organize their activities both in parallel and in close collaboration with Senegalese non-Christians. Most of these collectives carry out their events outside institutions' umbrella. Their relations with Catalan institutions are insignificant and often limited to petitioning public spaces for important events when access to public spaces is necessary.

\section{Claiming Particularities: Struggles against Exclusion and Racism}

Almost thirty five years have passed since La dialéctica de la identidad en Cataluña (the dialectic of identity in Catalonia) by Andrés Barreda (1985). Barrera's study contains an indepth sociological reflection to understand the complex phenomenon of group identities. It highlights the political rhetoric in the national identity building and strengthening process in Catalonia. A decade ago, Javier Pérez Andujar published Paseos con mi madre (Pérez Andujar 2011), which was followed by Jorge Javier Vázquez' autobiographical novel, $L a$ vida iba en serio (Vázquez 2013a). Despite the long horizon that separates these later two publications and Andrés Barrera's work, we remain at a crucial point of cultural clash in Catalonia that underpins otherness and racism in Catalan public institutions.

Desirée Bela-Lobedde's (2018) autobiographical book is part of the important productions of Black African descendants in Catalonia. "Being a black woman in Spain" intends to spark a debate on the burning issue of recognition in Catalonia, but also Spain. As an oeuvre of denunciation, Desirée does not claim for her Africanness, although she raises some interesting questions about the feeling of being black or Blackness. The text lacks a solid theoretical basis to enable the criticism of racism, and the style is very typical of a personal blog. However, Desirée achieved the goal of pointing out the discrimination and racism surrounding access to public spaces. As a young lady born to an African parent, the testimony of Desirée is valuable for understanding the context of social exclusion in Catalonia.

While the Senegalese and Equatoguineans cultural dynamics are marked by the consciousness of being part of groups shaped by culture and history, the strategy of Black African descendants focuses on the struggle against racism. In recent years, Black African descendants have undertaken some cultural dynamics. ${ }^{20}$ We can see that their concern remains focused on the struggle against racism. Born in Catalonia/Spain, the agenda of Black African descendants substantially differed from that of their parents. Their aspirations are no longer the preservation of African cultural heritage. Moreover, for them, African cultures represent a "ghosted sanctuary". Self definition and self representation became the basis of creating an imaginative world, where they can create conditions for the redemption of the Black community.

The dynamics of Black African descendants are mainly framed in discourse production. Their agenda and program action aim to reject the homogeneity of the Catalan society to claim a space for the expression of their particularity. Silvia Albert's plays, such as no es pais para negras "This is no country for negroes" (2016), provides us with some ideas with which to understand the concerns of Black African descendants. As Silvia herself states: "I was born and raised in a country where my nationality is not recognized because I have a different skin colour ... I grew up with the feeling of not belonging anywhere" ${ }^{21}$ This self schema depicts a psychological fissure where the idea of being and belonging points out the problem of presence and representation. 
Due to the complexity of cultural encounters in an environment marked by deep alienation and the social rejection of difference, this collective often deal with the crucial question of the social construction of "black identity". An awareness of the social conditioning of the idea of being and belonging to a marginalized community brings them to assume their Blackness. They try to answer so many questions: What does it mean to be black or African in Spain/Catalonia? Are they blacks, Africans or "Afro-Catalan/Afro-Spanish etc."? What does it mean to be Afro-Spanish/Afro-Catalan? Does the Catalan/Spanish national identity offer them the possibility to build their black referents? This conflict of identity underpins the traumatic self schema caused by the nonrecognition of racial and ethnic diversity and the rejection of the cultural background of their progenitors.

Some performances undertaken by Black African descendants in Catalonia show that their strategies remain a rejection of the stereotyped and discriminatory construction of the Catalan national identity. They experienced a trauma (of being nowhere), nourished by the genealogies of misery and the historical humiliation of the black nations due to slavery and colonization. Frantz Fanon described this psychological trauma: "In almost every case; we could see that the symptoms were, so to speak, like residues of emotional experiences" (Fanon 1963, p. 111). Fanon emphasizes that "it was not always a single event that was the cause of the symptom; most often, on the contrary, it arose out of multiple traumas, frequently analogous and repeated" (Ibid). Arguably, the collective memory of Black African descendants is often linked to traumatic scenes, wherein they represent "enemic residues" (Ibid).

Almost all of Silvia's plays are about racism and Black invisibility in Spanish/Catalan society. Both "No es pais para negras" and "blackface y otras verguenzas" depicts how Black African descendants are exposed to exclusion and humiliation both by society and Catalan public institutions. Silvia writes: " they do not realize that we are black, in fact, in Catalonia they are so busy with their affairs that they have not acknowledged that Black women exist" (Albert Sopale 2021, p. 341). As Desirée Bela, Silvia Albert does not claim an Africanness, nor the cultural background of Catalonia. Moreover, Silvia aims to raise the voices of Black African descendants to draw attention to their presence and claim their rights to be accounted not as passive citizens, but as an active part of society. That is, the claim is to be accounted for according to their particularities. It is a claim to be who they are and not what Catalan institutions want them to be.

Edouart Glissant (1997) explored the shallowness of judging the other according to one standard cultural autarchy, which loses sight of the exultant divergence of humanities. The interesting point to be emphasized here is that the possibility of being Catalan might not need to be defined by institutions; it does not have to be fixed or static and bounded by an essentialist understanding of national identity. The idea of being and belonging implies that every human being should consider the opacity of the other. Since to feel in solidarity with the other and build with her/him or to like what he/she does, it is not necessary to grasp him/her. It is not necessary to become him/her, nor to make him/her in one's image (Glissant 1997, p. 193). Indeed, the claim of Black Africans and their descendants is more than a claim for recognition. It is also a struggle against racism and the defense of radical diversity.

\section{Results: The Charnegroes and the Emergence of a Body Politic}

Considering the context of globalization, we can argue that the dynamics of Black Africans and their descendants rely on a cross cultural construction of identity from a cosmopolitan perspective. For instance, based on the idea of the Teranga, a Wolof term that means hospitality and building community, Senegalese associations are more than cultural organizations, for they remain open to all and serve as a mechanism of conflict resolution and peacebuilding. These are social groups where people gather efforts to help the community, celebrate a wedding, build a hospital in a town of origin, and build the relationship between their host society and their country of origin. The development 
of cultural dynamics and collective actions of Senegalese is inextricably linked to the environment and the conditions of departure.

However, Black Africans in Catalonia give a critical place to the conservation of the culture and the histories that have been transmitted to them for generations. The aim of both Equatoguineans and the Senegalese is to transmit the cultural legacy of their communities (bubi, fang, wolof, Mandinka etc.) to their descendants without a specific focus on national identity. Some of them have partially achieved this task. "When asked for her origin, my daughter, born in the Sant Pablo hospital in Barcelona of a Catalan father, often answers that she is Equatoguinean. She does not refer to the nationality of Equatorial Guinea but to her Bubi cultural heritage". ${ }^{22}$ This means that Black African migrants focus on fostering spirituality, telling stories, and promoting folklore to produce and maintain their collective memory while creating a space for representation.

Keeping in mind the description that surrounds the conceptual vagueness of being African or "Afro" in Catalonia/Spain, Black African descendants' strategy rejects the racist assumptions of Pujol's notion of "being Catalan" that poses the serious problem of being citizens. For instance, "when I arrived in Catalonia I could read and count in French. However, they put me in a separate class where I was supposed to learn Catalan while my colleagues learned mathematics and English." ${ }^{23}$ Figures like Silvia would become the spokespeople of Black African descendants in their struggle against racism and exclusion. Silvia offers, through theatre, the possibility to create a discourse that enables the resolution of two critical questions: the representation of real Black people and visualizing the reality of Black African descendants.

The agenda of Black African descendants differs radically from that of their parents. They do not seek to recreate a space of "Africanity" to reproduce the folklore their parents intended to preserve and promote. Instead, they experience a feeling of strangeness in their contact with Africa. Indeed, ties with Africa are full of images they created to fill the gap. Their imagination relies on a strange emotional relationship with Africa, shaped by broadcasting misery and the "backwardness" of the Black African fleeing the continent. The collective consciousness of Black African descendants is shaped by their individual experience and collective exclusion within Catalan/Spanish society.

To build the self image of an empowered Black community, Black African descendants select some references based on racial elements. The self referenced and self represented heroes are often selected from the Black diaspora (often among the Black heroes of the Americas). In their racially built identity, Africa is often superseded by the concept "Afro". The part of the history of Africa they claim is the one that took place before the slave trade of Black Africans and colonization. The reproduction of the glorious past of Africa helps them to fill the gap created by a single history, where being Black is a synonym of being savage, backward and naïve. In sum, one can argue that the postcolonial Africa of their parents cannot offer them anything other than wars, diseases, misery, and death. In terms of cultural expression and dynamics, the relationship with postcolonial Africa is practically the same as any white European.

I call this category of Black African descendants the charnegroes. Etymologically, charnegroe is the merging of the Spanish term Charnego and the English word "negroes". This "play on words" allows me to emphasize two basic ideas: ontologically, being charnegroe describes the idea of being black in a white dominant European society and rejects the political project of reifying citizens, such as in Catalonia. It is an act of refusal of Black African descendants in Catalonia that points out the complexity of cultural encounters and captures a significant self invention required in the challenge of the Catalan hegemonic cultural background.

The concept of charnegroe rejects the negative description of the Catalan discriminatory word of charnego. Being a charnegroe is an election compared to the institutional and imposed concepts of (Afro)Catalan and (Afro)spanish, which emphasize a duality between the "African identity" and the Catalan national identity. By addressing the cultural dynamics of Senegalese and Equatoguineans migrants, we have seen that being African entails 
a conceptual vagueness. If Africa itself is an invention (Mudimbe 1988), and although Africanness serves to reflect the cultural unity among African peoples (Diop 1979), thus we can argue that being "Afro ..." is a way of downplaying and excluding particularities.

There is a need for a practical explanation of being a Black African descendant beyond the trauma of slavery and colonization. From the understanding of postcolonial claims and the phenomenon of global migration, being charnegroe opposes the notion of Afrocatalan/Afrospanish, since the use of the epithet "Afro" (in Afro-Catalan, Afro-Spanish, etc.) does not provide anything except shaping a subcategory of Catalan/Spanish identity. Moreover, this "Afro epithetism" represents the construction of a "subaltern identity" which encapsulates the categories of Black Africans in an imaginary way, based on the genealogy of the race without denouncing racism. For instance, being Afro-Catalan-which some of Black African descendants identify themselves as-reproduces the very idea of Catalanism promoted by Catalan institutions as the foundation of Nous Catalans. It is nourished by a Eurocentric understanding of identity and highlights the nationalist and Jacobin character of belonging.

By conceptualizing the charnegroes, I also propose the possibility of escaping "nominal" Africanness. By so doing, charnegroe does not engage with an Afropolitan description of a diasporic identity (Mbembe 2007) since they do not seek a cosmopolitan African identity. On the contrary, the racial identity of the charnegroes imbibes Black African descendants' collective awareness in the building process of a body politic not necessarily connected to their African roots. The concept of charnegroe is then framed by cultural mobility, and the lived experiences of the descendants of Black Africans in a particular time and place, for instance, Catalonia, as we have seen. In this sense, the claims of the charnegroes neither embrace the Eurocentric construction of identity nor a universalist subalternity.

Ultimately, the concept of charnegroe describes the being in the world of Black African descendants, despite the will of Catalan institutions to place them into a taxonomy of national identity, appealing to false recognition and permissive cultural diversity. However, the self referring identity based on Blackness and belonging to a "Black nation", spread by black African descendants, sparks a passionate debate to be explored in depth. As far as Frantz Fanon puts it in a very provocative way: " ... the expression black nation is an entity, ... once cultural influences are removed, nothing else remains" (Fanon 2001, p. 26).

\section{Conclusions}

Arguably, common sense would provide us with an adequate means of determining people's association with the society to which they belong, instead of stereotypical ideas that tend to lead towards dogmatic proclamations to build nationhood. Ontological commitment among Black Africans and their descendants takes place in a sociopolitical tension. The claim for a national identity underpins the praise of the Catalan "differential fact" from Spaniards. After the organization of the referendum of October 2017, it became clear to the world that Catalans have their particularity, and their voices deserve to be heard. For the first time, Black Africans and their descendants could observe that even those who share their main cultural traits want to point out their differences. The Catalan/Spanish dispute then poses a dilemma of "being" and belonging for Black Africans and their descendants in Catalonia.

It was then justified for Black African descendants in Catalonia to claim their particularity and rights beyond the colonial legacy and postcolonial trauma. Their goal focuses on an inverted axiological activity, which makes possible a valorization of the rejected. This endowment of Blackness is brilliantly depicted by Jean-Paul Sartre ${ }^{24}$ and as Aimé Césaire (2005) puts it poetically, Nègre je suis, nègre je resterai. While African immigrants struggle to maintain a traditional cultural background, Black Africans' descendants build a new identity by claiming their Blackness. This metaphysical experience and ontological claim of Black Africans coincided with the political experience of national identity building in Catalonia. 
The cultural dynamics of Black Africans and their descendants are articulated around three axes of agenda setting strategies: (1) The claim of inclusion and recognizing their particularity in the society they belong, without having to adhere to the Catalan national identity. (2) Strengthening the intergroup relationship among Black Africans to promote collective consciousness. (3) Building new spaces for cultural representations of Black Africans and expression, to address social challenges and the struggle against racism.

Funding: This research did not receive any funding. The content of this publication represents the views of the authors only and is their sole responsibility. The European Commission does not accept any responsibility for use that may be made of the information it contains.

Institutional Review Board Statement: Ethical review and approval were waived for this study, due to information used are freely available in the public domain and the data used cannot be used to identify the participants, for any personal data is used.

Informed Consent Statement: Informed consent was obtained from all subjects involved in the study.

Conflicts of Interest: The author declares no conflict of interest.

\section{Notes}

$1 \quad$ For a better understing of postcolonialism please see (Said 1993; Mudimbe 1988; Nayar 2015; Radhakrishnan 1993; Bhabha 1994). Postcolonialism is a set of discursive methods that critically addresses modernity/postmodernity but also the postcolonial context to "rethink" the contemporary world. Postcolonialism focuses on the histories and cultures of the peoples, races, and groups excluded by imperialism and hegemonic cultures

2 Etymologically, I create this term from the merging of the Spanish term charnego and the English word "negroes". This "play on words" allows me to emphasize two basic ideas that encompass the concept of charnegroe.

3 Pujol write an opinion article to answer the critics on his book the text is still available online in the newpaper "El Pais": https:/ / elpais.com/diario/1977/03/25/espana/228092428_850215.html (accessed on 15 November 2020).

4 The full declaration of Artur Mas is available in the online version la Vanguardia. http://www.lavanguardia.com/magazine/ 20120224/54258645650/arturmas-generalitat-psoe-pp-cataluna.html. (I made the translation and adaptation of the original speech). (accessed on 15 November 2020).

5 See the argument of Artus Mas's original statement in https:/ / directe.larepublica.cat/noticia/11423/mas-veu-el-pacte-dimmigraciocom-un-acord-incomplet-i-delega-la-signatura-11423 (accessed on 15 November 2020).

6 Josep Antoni Duran i Lleida was one of the leaders of the coalition of political party CIU, the political formation of Jordi Pujol headed by Artus Mas.

7 The original speech in Catalan was "Aquí no hi cap tothom, i els que hi caben han d'estar plenament integrats"; the press conference of Duran I Lleida was held on on 14 May 2007 and is available on the website of naciodigital https://www. naciodigital.cat/index.php?seccio=noticies\&accio=veure\&id=5945 (accessed on 15 November 2020).

8 The article on the idea of the big house of Catalanism was published on 30 June 2014 in the newspaper Ara, and it is available at https:/ / www.ara.cat/politica / casa-gran-catalanisme-precedent-desus_1_2882490.html (accessed on 20 November 2020).

9 See interview with Edmundo Sepa Bonaba, the exdirector of Espai Afrocatala. https://www.elmundo.es/cataluna/2016/06/20 /5766c70aca4741da578b45ab.html (accessed on 10 January 2021).

10 Since 1995, SOS Racismo has published a yearly report on racism in Spain. the reports are available through https://sosracismo. eu/informe-sos/ (accessed on 10 November 2020).

11 Street vending is a cultural practice among the Senegalese community in Spain. It is enough to visit the ecosystem of Spanish cities to realize that most of those involved in selling in the street are Senegalese immigrants. Most of them are from rural areas. They start selling items on the street to survive in harsh living conditions. However, we should recognize that street vending is also a cultural practice. The practice of street selling is so widespread in the country of origin that it has given rise to terms like gorgorlu, a Wolof word that means "to get by as you can". Street vending activity has also given birth to other words using the English jargon like "hustle-man".

12 A face to face interview with guinean lady in Barcelona in Mayo 2019.

13 In a face to face interview with Guniean Lady ibid.

14 Phone interview with a member of the association Viyil, 12 November 2020.

15 In a phone conversation with the General Secretary of the Federation of the Senegalese Association of Catalonia (CASC), on 15 November 2020.

16 In conversation through Google Meet with the President of CASC, IN 12 November 2020. 
The Almoravids are an Arab tribe that dominated northern Africa and Spain during the second half of the 11th century and the first half of the 12 th.

18 While the colonizers occupied the political and economic life, the religious movement deployed strategies to prevent fashioning the faith and belief of the "indigenous". Spiritual leaders such as Ahmadou Bamba (1853-1927) founded the Murid brotherhood inspired by the Islamic branch of Sufism (Mbacke 1998). Malick Sy (1855-1922) and Baay Ibrahima Nas (1900-1975) would follow his example, but these texts would be rather influenced by the Tijania, also an expression of North African Sufism. The Layen brotherhood was founded by Limamou Laye (1843-1909). Limamou presented himself as the reincarnation of the prophet of Islam. Then and now, his followers insist that he had a special supernatural gift that enabled him to mediate between them and the almighty (Thomas 2012).

19 Phone interview with Abacar Thiakh, General coordinator of the Murid Dahira of Catalonia.

20 See for example Black Barcelona, the main event organized by Black descendants in Catalonia and where they focus the message to build a sense of belonging through artistic demonstrations https:/ / blackbarcelona.es / (accessed on 5 January 2021).

21 My translation. The original text by Silvia is written in Spanish and it appears on the official website of the play to which I had access on 25 December 2020. https:/ / noespaisparanegras.es/no-pais-negras-teatro-negro-todos/punto-de-partida/ (accessed on 25 December 2020).

22 In a face to face interview with Guinean Lady on 15 May 2019 at Altair book store.

23 Woman 25 years of Senegalese Origine, during an online debate organized by the CASC in December 2020.

24 One of the greatest French intellectuals who gives his support to the actors of the negritude movement, Jean-Paul Sartre prefaced the anthology of the new negro and Malagasy poetry directed by Léopold Sédar Senghor (2002). The text of Sartre is considered one of his greatest contributions to French literature.

\section{References}

Abid, Ed. D. 2017. Ethnography: Linking Theory and Practices. Indonesia English Department, Gorontalo State University 7: 601-5. [CrossRef]

Ainaud, Josep Maria. 1980. Immigració i reconstrucció nacional de Catalunya. Barcelona: Blume.

Albert Sopale, Silva. 2021. Blackface y otras vergüenzas. Acotaciones N 46: 339-61.

Añón, Jose Garcia, Antoni Llorente Ferreres, Ben Bradford, Jose Antonio García Sáez, and Andrés Gascón Cuenca. 2013. Identificación Policial por perfil étnico en España: Informe sobre experiencias y actitudes en relación con las actuaciones policiales. Valencia: Tirant lo Blanch.

Aramburu, Mikel. 2016. Vindicating the Charnego? Classism and segregation in Javier Pérez Andújar's and Jorge Javier Vázquez's autobiographical discourse. Revista de Dialectologia y Tradiciones Populares IXXI: 129-49. [CrossRef]

Asad, Talal. 1973. Anthropologyandthecolonialencounter. London: Ithaca Press.

Balboa, Juan. 1985. El reencuentro: el retorno del exiliado. Malabo: Ediciones Guinea.

Barreda, Andrés. 1985. La dialéctica de la identidad en Cataluña: Un estudio de antropología social. Madrid: Centro de investigaciones sociológicas.

Bela-Lobedde, Desirée. 2018. Ser mujer negra en España. Barcelona: Ediciones B.

Bhabha, Homi K. 1994. The Location of Culture. London: Routledge.

Blasser, Mario. 2013. Ontological Conflicts and the Stories of Peoples in Spite of Europe: Toward a Conversation on Political Ontology. Current Anthropology 54: 547-68. [CrossRef]

Bricker, Phillip. 2016. Ontological Commitment. Edited by Edward N. Zalta. Stanford: The Stanford Encyclopedia of Philosophy, Available online: https://plato.stanford.edu/entries/ontological-commitment/ (accessed on 20 April 2020).

Brown, Nadia, and Sarah Allen Gershon. 2017. Body politics. Politics, Groups, and Identities 5: 1-3. [CrossRef]

Bruschi, Francesca. 2005. Politique indigène et administration au Sénégal (1890-1920). Il Politico 70: 501-22.

Candel, Francesc. 1985. Els altres Catalans vint anys després. Barcelona: Edicions 62.

Carbonell, Francesc. 2006. L'acollida: Acompanyament d'alumnat nouvingut. Vic: Fundació Jaume Bofill.

Cash, John, and Catarina Kinnvall. 2017. Postcolonial bordering and ontological insecurities. Postcolonial Studies 20: 267-74. [CrossRef]

Césaire, Aimé. 2005. Nègre je suis, nègre je resterai. Entretien avec Françoise Vergès. Paris: Albin Michel.

Chapman, Roger. 2010. Culture Wars: An Encyclopedia of Issues, Viewpoints and Voices. Armonk, NY: M.E. Sharpe.

Cingolani, M. Stefano. 2015. La formació nacional de catalunya i el fet identitari dels catalans (785-1410). Barcelona: Generalitat de Catalunya.

Clua, Montserrat. 2011. Catalan, immigrants and charnegos: "race", "cultura" and "mixture" in Catalan Nationalist Rhetoric. Revista de Antropología Social 20: 55-75. [CrossRef]

Clua, Montserrat. 2014. Identity and Politics in Catalonia: The Rise of Independentism in Contemporary Catalonian Nationalism. Institut Català d'entropologia 19: 79-99.

Conversi, Daniele. 1997. The Basques, the Catalans and Spain. Reno: University of Nevada Press.

Council of Europe. 2008. White Paper on Intercultural Dialogue. "Living Together As Equals in Dignity". Starsbourg: Council of Europe Ministers of Foreign Affairs at their 118th Ministerial Session. 
de Castro Rodríguez, Mayca. 2019. Escritora, editora, lectora. La condición triangular de las letras afrohispanas a través de la práctica editorial de Remei Sipi Mayo". Lectora 25: 241-51. [CrossRef]

de Jong, Ferdinand. 2010. Remembering the Nation The Murid Maggal of Saint-Louis Senegal. Cahiers d'Études Africaines 50: $123-51$. [CrossRef]

Diagne, Souleymane Bachir, and Jean Loup Amselle. 2018. Enquetes d'Afrique. Universalism et pensée décolonial. Paris: Albin Michel.

Diop, Cheikh Anta. 1979. Nation nègre et Culture. Paris: Présence Africaine.

Diouf, Mamadou. 2000. Assimilation coloniale et identités religieuses de la civilité des originaires des Quatre Communes (Sénégal). Canadian Journal of African Studies 34. [CrossRef]

Ercan, S. A. 2012. Beyond Multiculturalism: A Deliberative Democratic Appproach to "Illiberal" Cultures'. Ph.D. thesis, Australian National University, Canberra, Australia.

Evita, Leoncio. 1996. Cuando los combes luchaban. Madrid: CSIC.

Fall, Abdoulaye. 2017. Migraciones y programas de asistencia a la migración senegalesa en Cataluña: Inmigración y retorno. Doctoral's thesis, Centre d'Estudis Demografics, Universitat Autónoma de Barcelona, Bellaterra, Spain.

Fanon, Frantz. 1963. The Wretched of the Earth. (Translation of Constance Farrington). Parsis: Présence Africaine.

Fanon, Frantz. 2001. Pour la révolution africaine. Ecrit Politiques. Paris: La découverte.

Fok, Lillian Y., Dinah M. Payne, and Christy M. Corey. 2016. Cultural Values, Utilitarian Orientation, and Ethical Decision Making: A Comparison of U.S. and Puerto Rican Professionals. Journal of Business Ethics 134: 263-79. [CrossRef]

Garcia Matin, Alberto, and Esteban Buch Sánchez. 2020. Se alquila? Racismo y Xenofobia en el mercado del alquiler. Mountain View: Creative Common.

Generalitat. 2005. Plan de Ciutadania i Immigració 2005-2008. Barcelona: Generalitat de Catalunya.

Generalitat. 2008. Pacte Nacional per a la Immigració. Barcelona: Generalitat de Catalunya.

Generalitat. 2014. Plan de Ciutadania i Immigració (2009-2014). Barcelona: Generalitat de Catalunya.

Generalitat. 2017. Citizenship and Migration Plan 2017-2020. Barcelona: Generalitat de Catalunya.

Giró-Miranda, Joaquin, and Ana Mata Romeu. 2013. Structural associations of senegalese in spain. Revista Internacional de Sociologia 71: 91-115. [CrossRef]

Glissant, Edouard. 1981. Le Discours Antillais. Paris: Edition Seuil.

Glissant, Edouard. 1990. Poétique de la Relation. Paris: Gallimard.

Glissant, Edouard. 1997. Poetic of Relation. Ann Arbor: The University of Michigan Press.

Glissant, Edouard. 2006. L'Afrique, les Afriques. Presence africaine. Paper presented at the 50th Anniversary of the 1st International Congress of Black Writers and Artists, Paris, France, September 19-22; Available online: https: / / www.freedomarchives. org/Documents /Finder/Black\%20Liberation\%20Disk/Black\%20Power!/SugahData/Journals/Presence.S.pdf (accessed on 10 January 2021).

Gozdecka, Dorota A., Selen A. Ercan, and Magdalena Kmak. 2014. From multiculturalism to post-multiculturalism: Trends and paradoxes. Journal of Sociology 50: 51-64. [CrossRef]

Grandhomme, Hélène. 2009. Connaissance de l'islam et pouvoir colonial: L'exemple de la France au Sénégal. French Colonial History 10: 171-88. [CrossRef]

Guibernau, Montserrat. 2014. Catalan Secessionism: Young People's Expectations and Political Change. The International Spectator: Italian Journal of International Affairs 49: 106-17. [CrossRef]

Habermas, Jürgen. 1998. The Inclusion of the Other: Studies in Political Theory. Translated by C. Cronin. Cambridge, MA: MIT Press.

Hainmueller, Jens, and Daniel J. Hopkins. 2014. Public Attitudes toward Immigration, Centre for Research and Analysis of Migration Department of Economics. Discussion Paper CDP15/13. Available online: https://cream-migration.org/publ_uploads/CDP_15 _13.pdf (accessed on 6 February 2021).

Huntington, Samuel P. 1993. The clash of civilizations? Foreign Affairs 72: 22-49. [CrossRef]

Kashima, Yoshihima. 2014. How can we capture cultural dynamics? Frontiers 5: 995. [CrossRef]

Kymlicka, Will. 2010. The Rise and Fall of Multiculturalism? New Debates on Inclusion and Accommodation in Diverse Societies'. In The Multiculturalism Backlash: European Discourses, Policies and Practices. Edited by S. Vertovec and S. Wessendorf. London: Routledge, pp. 32-50.

Levey, G. B. 2009. What Is Living and What Is Dead in Multiculturalism. Ethnicities 9: 75-93. [CrossRef]

Manent, Pierre. 2007. Democracy Without Nations? The Fate of Self-government in Europe Trans Paul Seaton. Wilington: ISI Books.

Mbacke, Khadim. 1998. La tariqua des mourides Rivista trimestrale di studi e documentazione dell'Istituto-italiano per l'Africa e l'Oriente. Africa 53: 102-120.

Mbana, Juanquin. 2004. Brujería fang en Guinea Ecuatorial. El Mbwo. Madrid: SIAL Ediciones.

Mbembe, Achille. 2007. Afropolitanism. In Africa Remix. Johannesburg: Jacana Media.

Morales, Laura, Jean Benoi Pilet, and Didier Ruedin. 2015. The Gap between Public Preferences and Policies on Immigration: A Comparative Examination of the Effect of Politicization on Policy Congruence. Journal of Ethnic and Migration Studies 41: 1495-516. [CrossRef]

Mudimbe, V. Yves. 1988. The Invention of Africa: Gnosis, Philosophy, and the Order of Knowledge. Indiana: Indiana University Press.

Nandy, Ashis. 1983. The Intimate Enemy: Loss and Recovery of Self under the Colonialism. Delhi: Oxford University Press.

Nayar, Pramod K. 2015. The Postcolonial Studies Dictionary. Malden and Oxford: John Wiley \& Sons, Ltd. 
Ndongo, Biyogo D. 1977. Historia y Tragedia de Guinea Ecuatorial. Madrid: Cambio16.

Nsue-Angué, María. 2008. Ekomo. Madrid: Sial.

Parés, E. Español, and S. Bartomeu Borràs. 1999. Llibre d'or dels parcs naturals de Catalunya. Barcelona: Generalitat de Catalunya.

Penninx, R., With S. Blom, Tiziana Caponio, Blanca Garcés Mascareñas, B. P. Matusz Protasiewicz, and Hanna Schwarz. 2014. European Cities and Their Migrant Integration Policies: A State-of-the-Art Study for the Knowledge for Integration Governance (KING) Project. Milan: ISMU Foundation.

Pérez Andujar, Javier. 2011. Paseos con mi madre. Barcelona: Tusquets.

Pujol, Jordi. 1976. La Inmigración, problema y esperanza de Cataluña. Barcelona: Convergència Democràtica de Catalunya.

Radhakrishnan, R. 1993. Postcoloniality and The Boundaries of Identity. In Autumn Callaloo. On "Post-Colonial Discourse": A Special Issue. Baltimore: The Johns Hopkins University Press, pp. 750-71.

Rex, John. 1996. National Identity in the Democratic Multi-Cultural State. In Centre for Research in Ethnic Relations. Edited by John Stone. Hoboken: John Wiley and Sons. [CrossRef]

Roshwald, Aviel. 2016. Civic and Ethnic Nationalism. In The Wiley Blackwell Encyclopedia of Race, Ethnicity, and Nationalism. Edited by John Stone, Rutledge M. Dennis, Polly S. Rizova, Anthony D. Smith and Xiaoshuo Hou. Hoboken: JohnWiley \& Sons.

Rubio-Carbonero, Gema, and Ricard Zapata-Barrero. 2017. Monitoring discriminatory political discourse on immigration. Discourse $\mathcal{E}$ Society 28: 204-25. [CrossRef]

Sabatier, Peggy R. 1978. "Elite" Education in French West Africa: The Era of Limits, 1903-1945. The International Journal of African Historical Studies 11: 247-66. [CrossRef]

Said, Edwar. 1993. Culture and Imperialism. London: Chatto \& Windus.

Scott, J. C. 1990. Domination and the Arts of Resistance: Hidden transcripts. Yale: Yale University Press.

Sembène, Ousmane. 1977. Ceddo. Dakar: Felmi Domirew.

Senghor, L. S. 2002. Anthologie de la nouvelle poésie nègre et malgache de langue française, 6th ed. Paris: PUF.

Sepa Bonaba, Edmundo. 1993. Es negres catalans: la immigració africana a Catalunya. Barcelona: Alta Fulla.

Sepa Bonaba, Edmundo. 2017. Convergentes convenientes o intruso. Barcelona: Wanafrica.

Shafir, Gershon. 1995. Immigrants and Nationalists. Nueva York: State University of New York Press.

Sobresques, Jaume. 2015. Consolidació i majoria dedat del fet identitari catala (1410-1714). Barcelona: Generalitat de Catalunya.

Solé, Carlota. 1982. Los inmigrantes en la sociedad y la cultura catalanas. Barcelona: Edicions 62.

Sow, Pape. 2003. Senegaleses y gambianos en Cataluña (España): Análisis geo-sociológica de sus redes especiales y sociales. Doctoral thesis, Departament de Geografia, Facultad de Lletras i filosofía, Universitat Autónoma de Barcelona, Bellaterra, Spain.

Spivak, Gayatri Chakravorty. 2010. "Can the Subaltern Speak?": Revised Edition, from the "History" Chater of Critique of Postcolonial Reason. In Can the Subaltern Speak?: Reflections on the History of an Idea. Edited by Morris Rosalind C. New York: Columbia University Press, pp. 21-78.

Taylor, Charles. 1992. Multiculturalism and 'the Politics of Recognition'. Princeton: Princeton University Press.

Thomas, Douglas H. 2012. Sufism, mahdism and Nationalism Limamou Laye and the Layenes of Senegal. London: Bloomsbury Publishing Plc.

Vázquez, Jorge J. 2013a. La vida iba en serio. Barcelona: Planeta.

Vázquez, Silvina. 2013b. Identidad nacional y autogobierno. Un estudio cualitativo sobre las configuraciones identitarias nacionales en la Cataluña contemporánea. Barcelona: Centre d'Estudis d'Opinió.

Vertovec, Steven. 2010. Towards Post-multiculturalism. Changing Communities, Conditions and Contexts of Diversity'. International Social Science Journal 61: 83-95. [CrossRef]

Vertovec, Steven. 2011. The Cultural Politics of Nation and Migration. Annual Review of Anthropology 40: 241-56. [CrossRef]

Zapata-Barero, Ricard. 2000. La época de la inmigración y su tratamiento politogico: Una nota bibliográfica. Revista Española de Ciencias Políticas 3: 167-80.

Zapata-Barero, Ricard, Ferran Requejo, David Sancho, and Borja Rius. 2003. Estudi de les polítiques d'integració dels immigrants a partir del disseny dels plans comarcals enfocament comarcal per a la gestió local de la immigració. Barcelona: Universitat Pompeu Fabra.

Zapata-Barero, Ricard, Elizabeth Gonzalez, and Elena Sánchez Montijano. 2008. El discurso político y la inmigración en España y en la UE. Madrid. Documentos del observatorio permanente de la inmigración. Madrid: Ministerio de Trabajo e Inmigración. 